lene intervenerer mer spesifikt i patofysiologien ved psoriasis og gir rask og vedvarende inflammasjonskontroll, med stor bedring av livskvalitet og forhåpentligvis også redusert forekomst av komorbiditet. Denne helsegevinsten må veies opp mot langtidsrisiko og kostnader. Kapitlet om monitorering av alefaceptbehandling er irrelevant for norske leger, og omtalen av behandling med efalizumab burde tas bort, da preparatet er fjernet fra markedet etter påvisning av alvorlige nevrologiske bivirkninger.

Det hele avsluttes med et spennende kapittel om fremtidsperspektiver i psoriasisbehandlingen. Her gjennomgås terapier som kan påvirke de to viktigste angrepspunktene i psoriasisbehandlingen: keratinocyttene og immunsystemet. Lovende terapeutiske strategier kan være psoriasisgener som påvirker psoriasisfenotype, interferens med signalsystemer som påvirker inflammasjonsprosessen, inhibisjon av aktiverte T-celler, blokkering av proinflammatoriske cytokiner, hemmet leukocyttmoblisering og antiangiogenese.

Management of psoriasis gir en kortfattet oppdatering av aktuell psoriasisbehandling. Den kan anbefales til alle leger som direkte eller indirekte er involvert $\mathrm{i}$ behandling av pasienter med denne sykdommen. Ledende internasjonale eksperter på området har bidratt med ti velskrevne kapitler, og boken er godt redigert. Det er imidlertid verdt å merke seg at den er utgitt med støtte fra legemiddelfirmaer som er tungt involvert i biologiske legemidler.

\section{Cato Mørk}

Hudlegekontoret på Hønefoss

Osloveien 10

3511 Hønefoss

\section{Ny bok om hepatocellulært karsinom}

Knawy BA, Reddy KR, Bolondi L, red.

Hepatocellular carcinoma

A practical approach. $162 \mathrm{~s}$, tab, ill. London: Informa Healthcare, 2009. Pris GBP 100 ISBN 978-0-4154-8080-2

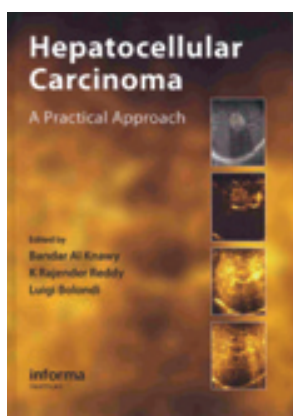

Hepatocellulært karsinom (HCC) er sjeldent i Norge, det er ca. 125 nye tilfeller årlig. Forekomsten er høy i land med endemisk forekommende hepatitt B og hepatitt C, og hepatocellulært karsinom er på verdensbasis den 3. vanligste kreftrelaterte dødsårsak. Insidensen er stigende i Vesten. Informa Healthcare har utgitt en leservennlig lærebok om sykdommen som dekker de fleste aspekter klinikere blir involvert i. Den er inndelt i tre seksjoner i første del beskrives epidemiologi, patogenese, overvåking/forebygging, $\mathrm{i}$ andre del diagnostiske temaer og $\mathrm{i}$ tredje del aktuelle behandlingsvalg. Totalt er det 12 kapitler med forskjellige forfattere fra sentre i USA, Kina, Japan, Australia og Italia.

Formålet med utgivelsen synes å være å gi klinikere en innføring i og en oppdatert oversikt over faget. Kapitlene er konsentrerte og kortfattede, og det er rikelig med referanser. Dette bærer likevel preg av å være en førsteutgivelse. Jeg savner visse detaljer. Selv om Child-Pugh-skår er kjent for leger som arbeider med leversykdommer, burde en tabell for denne vært presentert i kapitlet om stadieinndelingssystemer, da den inngår som en variabel i enkelte av disse. Videre er det i kapitlet om ablative behandlinger ikke omtalt at man ved flere sentre studerer stereotaktisk strålebehandling som et alternativ for enkelte pasienter. Jeg vil likevel absolutt anbefale Hepatocellular carcinoma siden den gir en fin innføring om denne krefttypen og vil gi leseren en oppdatert forståelse av faget. Den er relevant for onkologer, gastroenterologer, leverkirurger og intervensjonsradiologer, særlig for utdanningskandidater i de nevnte spesialiteter, men også for alle interesserte leger som kommer i berøring med dette fagfeltet.

\section{Geir Olav Hjortland}

Avdeling for kreftbehandling

Oslo universitetssykehus, Radiumhospitalet

\section{Med dr. House i lommen}

Raftery AT, Lim E, Ostor AJK.

Churchill's pocketbook of differential diagnosis

3. utg. 596 s, tab. Churchill's Pocketbooks. London: Churchill Livingstone Elsevier, 2009. Pris GBP 23

ISBN 978-0-7020-3222-6

I denne håndboken i differensialdiagnostikk er det 105 separate kapitler for kliniske problemstillinger som magesmerter, ryggsmerter, kul i brystet, brystsmerter, koma, forvirring, forstoppelse, svimmelhet, fotsår, utslett, feber, kløe, synkope, tørste, tremor, utflod, kjevesmerter, rødt øye ... Listen er lang og dekker svært mange av de symptomdiagnoser man står overfor i en klinisk hverdag. I tillegg er det en separat seksjon med 14 biokjemiske problemstillinger, som hyponatremi, hyperkalemi mv., samt en egen seksjon for hematologiske tilstander som anemi og leukopeni.

Håndboken skiller seg fra metode- og prosedyrebøkene ved at man har tatt utgangspunkt i symptomer og utredning fremfor å komme med spesifikke behand- lingsanbefalinger for hver enkelt diagnose. Den er nyttig som veiledning i klinisk resonnering à la dr. House (fra den populære fjernsynsserien) og kan gjøre yngre leger i stand til å imponere kolleger og overordnede med fornuftige kliniske resonnementer og gode forslag til videre utredning og diagnostikk. For erfarne leger er dette morsom lesing og nyttig repetisjon i differensialdiagnostikk rundt et stort antall kliniske problemstillinger. Metodebøkene vil selvsagt fortsatt behøves når diagnosen er stilt og man er usikker på hvordan behandlingen skal gjennomføres.

Den er i slitesterk plastinnbinding og passe stor for frakkelommen, men kan gjerne også få plass i bokhyllen på vaktrommet der sykepleiere vil kunne glede seg over den. Det grafiske oppsettet er delikat, med punktvis oppstilling av differensialdiagnosene påført fargekoder for å angi sannsynligheten (prevalensen) av hver diagnose gitt den kliniske problemstillingen. Det er ingen bilder eller illustrasjoner, men det savnes heller ikke. Kapitlene er inndelt i underkapitler for anamneseopptak, klinisk undersøkelse og videre undersøkelser. Språket er godt og teksten kortfattet, men instruktiv. De faglige anbefalingene er oppdaterte og i tråd med norske forhold (det kan nevnes at britene holder fast ved måling av protrombintid fremfor INR-nivå, men det skjemmer lite i en ellers praktfull håndbok i differensialdiagnostikk). Til sist i hvert kapittel er et tips om forhold man bør være spesielt oppmerksom på.

Enkelte kapitler savnes, for eksempel et om krampeanfall, som riktignok nevnes under svimmelhet og synkope, men som kunne vært diskutert $\mathrm{i}$ et selvstendig kapittel. Den viktigste innvendingen er nok at stikkordregisteret kunne vært fyldigere, med separate oppføringer for alle symptomer som nevnes i hvert av kapitlene. For eksempel nevnes ikke flushing i stikkordregisteret, mens dette helt adekvat nevnes under Sweating abnormalities og Diarrhoea som symptom på karsinoid syndrom. Andre nøkkelord som burde vært separate oppslagsord i stikkordregisteret, er «fever», «fatigue» og «nose bleed». Riktignok finner man i stikkordregisteret «pyrexia», «tiredness» og «epistaxis» (sistnevnte med henvisning til kapitlene Haematemesis og Haemoptysis), men leseren burde slippe å lete med lys og lykte for å finne frem til der disse tilstandene diskuteres.

Omfanget av en slik utgivelse må selvsagt begrenses for at den skal få plass i en frakkelomme. Etter min mening har forfatterne lyktes i å lage en hendig lommeveiledning i klinisk tenkning og differensialdiagnostikk, og den anbefales på det varmeste.

\section{Arne Westgaard}

Kirurgisk avdeling

Oslo universitetssykehus, Rikshospitalet 